\title{
Use of Monoclonal Antibodies for the Identification of Leishmania spp. Isolated from Humans and Wild Rodents in the State of Campeche, Mexico
}

\author{
Silvia B Canto-Lara, Nicole R Van Wynsberghe, Alberto Vargas-González, \\ Fanny F Ojeda-Farfán, Fernando J Andrade-Narváez ${ }^{+}$
}

\author{
Universidad Autónoma de Yucatán, Centro de Investigaciones Regionales “Dr Hideyo Noguchi”, \\ Laboratorio de Inmunología, Apdo. Postal 2-1277, CP 97240, Mérida, Yucatán, México
}

The genus Leishmania includes 30 described species which infect a wide variety of mammalian hosts. The precise identification of leishmanial parasites at the species level is very important in order to determine whether an organism, causing the disease in a given area, is of the same biotype as that found in suspected mammalian reservoirs. The objectives of the present study were (1) to identify leishmanial parasites isolated from humans and wild rodents from the State of Campeche, an endemic focus of localized cutaneous leishmaniasis (LCL) in southern Mexico, using an indirect immunofluorescent assay (IFA) with monoclonal antibodies (Mabs); and (2) to determine if the parasites of the two types of hosts were of the same biotype. All the wild rodents (six Ototylomys phyllotis, eight Oryzomys melanotis, five Peromyscus yucatanicus and two Sigmodon hispidus) and 96\% (24/25) of the human isolates were identified as Leishmania (L.) mexicana confirming that this specific LCL focus is a wild zoonosis. The presence of one human isolate of $\mathrm{L}$. (Viannia) braziliensis in the State of Campeche, confirmed the importance of an accurate taxonomic identification at species level.

Key words: Leishmania (Leishmania) mexicana - Leishmania (Viannia) braziliensis - monoclonal antibodies human - rodents - Mexico

Recent studies in epidemiology and molecular characterization of the New World leishmaniases have revealed that the genus Leishmania Ross, 1903 (Protozoa: Trypanosomatidae) is far more complex than originally thought (Grimaldi \& Tesh 1993, Cupolillo et al. 1994, Pérez-Mutul et al. 1994, Shaw 1994, Lainson 1997). The genus comprises 30 species which infect a wide variety of mammalian hosts (wild or domestic) and vectors (Grimaldi et al. 1991, Rebollar-Téllez et al. 1995, 1996a,b). Each of the New World species of Leishmania has unique ecological and geographical distributions (Grimaldi et al. 1989, Grimaldi \& Tesh 1993). From an epidemiological point of view and disease-control stand-point, it is very important to know whether an organism, causing the disease in a given area, is of the same biotype as that found in suspected mammalian reservoirs (WHO 1990).

\footnotetext{
This investigation received support from the UNDP/ World Bank/WHO Special Program for Tropical Diseases Research (TDR): RCS/TDR/WHO 900248.

+Corresponding author. Fax: (99) 236120. E-mail: anarvaez@tunku.uady.mx.

Received 11 February 1998

Accepted 1 February 1999
}

Localized cutaneous leishmaniasis (LCL) in the peninsula of Yucatán, Mexico, known as the "Chiclero's Ulcer", was described by Seidelin in 1912. Thereafter, additional cases of the disease were reported and the forest was considered an endemic focus of LCL (Beltrán \& Bustamante 1942, Biagi et al. 1957, Andrade-Narváez et al. 1990, Ramírez-Fraire 1992, Chablé-Santos 1994, Rebollar-Téllez 1995). Leishmania (L.) mexicana Biagi, 1953 emend. Garnham, 1962 was considered the main agent based on the clinical and epidemiological features of the disease (Biagi 1953b, Lainson \& Strangways-Dixon 1963, AlbertosAlpuche et al. 1996), and on the biological characteristics of the parasite in laboratory animals (Biagi 1953a, Biagi \& Velasco 1967).

Seventy-five leishmanial isolates from humans cases of LCL from the State of Campeche have been characterized by isoenzyme markers. Seventy (93.3\%) were identified as $L$. (L.) mexicana and five $(6.7 \%$ ) were L. (Viannia) braziliensis Viannia, 1911 emend. Matta, 1916 (Cárdenas-Marrufo 1993, Canto-Lara et al. 1998). Isolates from two wild rodents (one Oryzomys melanotis Thomas, 1893, and one Sigmodon hispidus Say and Ord, 1825) have been characterized as $L$. (L.) mexicana with monoclonal antibodies (Mabs) using an indirect immunofluorescent assay (IFA) (Chablé-Santos et 
al. 1995, Ojeda-Farfán 1996), but the parasites from other infected species of rodents have yet to be characterized. The objectives of the present study were (1) to identify leishmanial parasites isolated from humans and four species of wild rodents from the State of Campeche, Mexico, using IFA with Mabs; and (2) to determine if the parasites of both types of hosts were of the same biotype.

\section{MATERIALS AND METHODS}

Study area - The study area was the forest of the State of Campeche, Mexico. This area is an endemic focus of LCL probably due to its ecological conditions. A medium-height tropical forest covers about $59 \%$ of Campeche, the humidity reaches $80 \%$, the annual rainfall is around $1400 \mathrm{~mm}$, and the average temperature is $27^{\circ} \mathrm{C}$ (Flores \& Espejel Carvajal 1994). The rodents were trapped at $8 \mathrm{~km}$ southeast of La Libertad, a small village located $24 \mathrm{~km}$ east of Escarcega (previously described in Ramírez-Fraire 1992, Chablé-Santos 1994, Rebollar-Tellez 1995, Chablé-Santos et al. 1995).

Isolation of parasites - From September 1993 to May 1995, isolates of Leishmania were obtained from patients of LCL who became infected in the State of Campeche. Parasites were also obtained from small terrestrial wild rodents which were caught in collapsible Sherman traps from February 1993 to March 1994 (Chablé-Santos 1994, Chablé-Santos et al. 1995) and kept in captivity in the animal-care facilities of the Centre of Regional Research, University of Yucatán, Mérida, Yucatán, Mexico.

Parasites were isolated by needle aspirates from the edge of lesions in human cases and from the base of the tail in rodents. Aspirates were inoculated into a tube of Senekjie's modified medium and kept at $22^{\circ} \mathrm{C}$ (Weigle et al. 1987). After initial growth in cultures tubes, the parasites multiplied and were mass cultivated for Mabs analyses.

Mabs identification - The species of Leishmania were identified by IFA using Mabs (as previously described in Chablé-Santos et al. 1995). A panel of species- and complex-specific Mabs of both subgenera Leishmania (M3, M7, and M8) and Viannia (B4, B12, B16, and B19) were used (Mabs generously donated by Dr D McMahon-Pratt, Yale University, USA and Dr F Modabber TDR/WHO, Switzerland). The following cultures of World Health Organization (WHO) reference strains were used as control: $L$. (L.) mexicana (MHOM/BZ/82/ Bel21), L. (L.) amazonensis Lainson and Shaw, 1972 (MHOM/BR/73/M2269), L. (V.) braziliensis (MHOM/BR/84/LTB300), L. (V.) guyanensis Floch, 1954 (MHOM/BR/75/M4147), L. (V.) panamensis Lainson and Shaw, 1972 (MHOM/PA/ 71/LS94). Promastigotes were washed three times in phosphate-buffered saline, distributed on multispots slides, air-dried, fixed for $10 \mathrm{~min}$ in acetone at $24^{\circ} \mathrm{C}$ and stored at $-70^{\circ} \mathrm{C}$ until used. Optimal dilutions of Mabs and fluorescein isothiocyanateconjugated immunoglobulin $\mathrm{G}$ ( $\mathrm{IgG}$ ) (goat anti-mouse IgG heavy-light chains fraction) were $1: 50$ and $1: 25$ respectively.

\section{RESULTS}

Between September 1993 and May 1995, a total of 81 cases of LCL from the State of Campeche were confirmed by at least one of the parasitological analyses employed (smear, biopsy and isolation-culture). From those cases, 25 isolates were successfully cultivated. Twenty-four (96\%) reacted with M8 and M7 and were identified as $L$. $(L$.) mexicana. Only one (4\%), reacting with B12 and B16, was considered as L. (V.) braziliensis.

Between February 1993 and March 1994, 21 strains were isolated from four species of wild rodents: six Ototylomys phyllotis Merriam, 1901; eight $O$. melanotis; five Peromyscus yucatanicus J.A. Allen and Chapman, 1897; and two S. hispidus. As shown in Table, all the isolates from wild rodents reacted with M7 and M8 and thus, were identified as $L$. $(L$.) mexicana. No differences in reactivity patterns were found among the different strains of $L$. (L.) mexicana from humans and from wild rodents.

\section{DISCUSSION}

Because of the complexity of leishmaniases and the huge amount of information collected worldwide, the WHO (1990) emphasized the importance of an accurate taxonomical identification of the species of Leishmania as a basis for further comparisons and discussions. Monoclonal antibodies that distinguish New World species of Leishmania have been produced and tested (McMahon-Pratt \& David 1981, McMahon-Pratt et al. 1985, Grimaldi et al. 1989). The results of the high specificity of Mabs for selected species of Leishmania have been confirmed using a large sample of isolates from humans, wild mammals, and sand flies; and in addition Mabs results were confirmed using in parallel isoenzyme electophoresis and other molecular techniques at the genotypic level (CantoLara unpublished data, Mimori et al. 1989, Grimaldi et al. 1989). In the present study, 96\% $(\mathrm{N}=25)$ of the human isolates were identified with Mabs as $L$. (L.) mexicana. The presence of one human isolate of $L$. $(V$.) braziliensis in the LCL focus of the southeast of Mexico, confirmed the importance of an accurate taxonomic identification at the species level. This newly-found autochtonous LCL in the State of Campeche implies that two transmission cycles of LCL co-exist 
TABLE

Results of indirect immunofluorescent assay with Leishmania-specific monoclonal antibodies on smears of WHO reference strains and wild rodents isolates

\begin{tabular}{|c|c|c|c|c|c|c|c|c|}
\hline \multirow[t]{2}{*}{$\begin{array}{l}\text { Strain/isolate } \\
\text { code }\end{array}$} & \multicolumn{7}{|c|}{$\begin{array}{l}\text { Monoclonal antibody } \\
\text { code number }\end{array}$} & \multirow[t]{2}{*}{$\begin{array}{l}\text { Parasite } \\
\text { identification }\end{array}$} \\
\hline & M7 & M8 & M3 & B12 & $\mathrm{B} 4$ & B16 & B19 & \\
\hline \multicolumn{9}{|l|}{ WHO reference strains } \\
\hline MHOM/BZ/82/Bel 21 & + & + & - & - & - & - & - & $L(L)$ mexicana \\
\hline MHOM/BR/73/M2269 & + & - & + & - & - & - & - & $L(L)$ amazonensis \\
\hline MHOM/BR/84/LTB300 & - & - & - & + & - & + & - & $L(V)$ braziliensis \\
\hline MHOM/BR/75/M4147 & - & - & - & + & - & - & + & $L(V)$ guyamensis \\
\hline MHOM/PA/71/LS94 & - & - & - & + & + & - & - & $L(V)$ panamensis \\
\hline \multicolumn{9}{|l|}{ Wild rodents isolates. } \\
\hline MSIG/MX/93/SA2 & + & + & - & - & - & - & - & $L(L)$ mexicana \\
\hline MSIG/MX/94/SN5 & + & + & - & - & - & - & - & $L(L)$ mexicana \\
\hline MPER/MX/94/P15a & + & + & - & - & - & - & - & $L(L)$ mexicana \\
\hline MPER/MX/94/P1a & + & + & - & - & - & - & - & $L(L)$ mexicana \\
\hline MPER/MX/94/P3b & + & + & - & - & - & - & - & $L(L)$ mexicana \\
\hline MPER/MX/94/PO11 & + & + & - & - & - & - & - & $L(L)$ mexicana \\
\hline MPER/MX/94/P8 & + & + & - & - & - & - & - & $L(L)$ mexicana \\
\hline MORY/MX/93/Or14b & + & + & - & - & - & - & - & $L(L)$ mexicana \\
\hline MORY/MX/93/OrK6 & + & + & - & - & - & - & - & $L(L)$ mexicana \\
\hline MORY/MX/93/Or12a & + & + & - & - & - & - & - & $L(L)$ mexicana \\
\hline MORY/MX/93/OrN1 & + & + & - & - & - & - & - & $L(L)$ mexicana \\
\hline MORY/MX/94/OrF9 & + & + & - & - & - & - & - & $L(L)$ mexicana \\
\hline MORY/MX/94/OrC8 & + & + & - & - & - & - & - & $L(L)$ mexicana \\
\hline MORY/MX/94/OrD9 & + & + & - & - & - & - & - & $L(L)$ mexicana \\
\hline MORY/MX/OrC9 & + & + & - & - & - & - & - & $L(L)$ mexicana \\
\hline MOTO/MX/93/OtK5 & + & + & - & - & - & - & - & $L(L)$ mexicana \\
\hline MOTO/MX/94/Ot6a & + & + & - & - & - & - & - & $L(L)$ mexicana \\
\hline MOTO/MX/94/OtB4 & + & + & - & - & - & - & - & $L(L)$ mexicana \\
\hline MOTO/MX/94/OtC4' & + & + & - & - & - & - & - & $L(L)$ mexicana \\
\hline MOTO/MX/94/OtS9 & + & + & - & - & - & - & - & $L(L)$ mexicana \\
\hline МOTO/MX/94/OtQ9 & + & + & - & - & - & - & - & $L(L)$ mexicana \\
\hline
\end{tabular}

in the same focus. Because of its potential high virulence, the transmission cycle of $L$. $(V$. braziliensis, its response to therapy, and the prognosis in the focus should be studied.

The present study identified $L$. (L.) mexicana in four species of wild rodents: the black-eared ricerat, O. melanotis; the hispid cotton-rat, S. hispidus; the big-eared climbing rat, O. phyllotis; and the Yucatán deer-mouse, P. yucatanicus. In Belize, eight $O$. phyllotis and one $S$. hispidus have been found infected (Lainson \& Strangways-Dixon 1964, Disney 1968). The species of the parasite was never characterized but according to its behaviour, was thought to be $L$. (L.) mexicana (Lainson 1987). In Campeche, L. (L.) mexicana had only been identified in two samples from wild rodents: one S. hispidus and one O. melanotis (Chablé-Santos et al. 1995). Thus, the present study confirmed the presence of $L$. (L.) mexicana in $S$. hispidus and $O$. melanotis, and identified the same parasite in two new species of rodents $O$. phyllotis and $P$. yucatanicus which is an endemic species of the peninsula of Yucatán.

However, the direct incrimination of a mammal as a primary reservoir host requires that it is demonstrated that the parasite population needs this particular mammal for its maintenance in that specific focus. This demands extensive ecological studies and direct incrimination is generally not possible. For this reason WHO (1990) has estab- 
lished some criteria to define a primary reservoir host. One of them and probably the most important, is to demonstrate that the strain of parasite in a given focus is of the same biotype in both the mammal reservoir and human. In the present study, $L$. (L.) mexicana was characterized, by IFA using Mabs, in both $96 \%(\mathrm{~N}=25)$ of the human cases and $100 \%(\mathrm{~N}=21)$ of the rodent samples which demonstrated that the strains were from the same biotype and that this specific LCL is a wild zoonosis in the State of Campeche. Thus, one or more species of wild rodents might act as a reservoir host for $L$. (L.) mexicana. The four other criteria to define a primary reservoir are under study.

\section{ACKNOWLEDGEMENTS}

To Dr Diane McMahon-Pratt (Yale University) and Dr F Modabber (TDR/WHO) for providing the MAbs; the administration of the "Centro de Investigaciones Regionales" for their help in the organization of the field trips; the people of La Libertad who provided facilities necessary for the development of this research; the staff of the animal care; Alma G Damián-Centeno for her help with the parasitology; the team of the Laboratory of Immunology for their support during this research; and Nelly E Albertos-Alpuche, Dr Eric Dumonteil, and Nubia A Rivero-Cárdenas for their careful editing of the manuscript.

\section{REFERENCES}

Albertos-Alpuche NE, Andrade-Narváez FJ, BurgosPatrón JP, Vázquez-Pérez A 1996. Leishmaniasis cutánea localizada: índice alérgico en la comunidad de Becanchén, Tekax, Yucatán, México. Rev Bioméd 7: 11-18.

Andrade-Narváez FJ, Simmonds-Díaz E, Rico-Aguilar S, Andrade-Narváez M, Palomo-Cetina A, CantoLara SB, García-Miss MR, Madera-Sevilla M, Albertos-Alpuche NE 1990. Incidence of localized cutaneous leishmaniasis (chiclero's ulcer) in Mexico. Trans R Soc Trop Med Hyg 84: 219-220.

Beltrán E, Bustamante ME 1942. Datos epidemiológicos acerca de la "úlcera de los chicleros" (leishmaniasis americana) en México. Rev Inst Salub Enferm Trop 3: 1-28.

Biagi F 1953a. Algunos comentarios sobre las leishmaniasis y sus agentes etiológicos. Leishmania tropica mexicana, nueva sub-especie. Medicina (México) 33: 1-6.

Biagi F 1953b. Síntesis de 70 historias clínicas de leishmaniasis tegumentaria en México ("úlcera del chiclero"). Medicina (México) 33: 385-396.

Biagi F, Velasco O 1967. Identidad de Leishmania mexicana y su comportamiento en animales de laboratorio. Gaceta Med Méx 97: 1412-1417.

Biagi F, Marroquín F, González M 1957. Distribución geográfica de la leishmaniasis en México. Medicina (México) 37: 444-446.

Canto-Lara SB, Cárdenas-Marrufo MF, Vargas-González A, Andrade-Narváez FJ 1998. Isoenzyme charac- terization of Leishmania isolated from human cases with localized cutaneous leishmaniasis from the State of Campeche, Mexico. Am J Trop Med Hyg 58: 444447.

Cárdenas Marrufo MF 1993. Caracterización Isoenzimática de Aislados de Pacientes con Leishmaniasis Cutánea Localizada Mexicana (Ulcera de los Chicleros) de un Area Endémica del Estado de Campeche, MSc Thesis, Universidad Autónoma de Yucatán, Mérida, Yucatán, Mexico, 47 pp.

Chablé-Santos JB 1994. Estudio de los Roedores Silvestres como Posibles Reservorios de Leishmaniasis Cutánea Localizada (LCL) en un Area Endémica de la Enfermedad en el Estado de Campeche, México, Undergraduate Thesis, Universidad Autónoma de Yucatán, Mérida, Yucatán, México, 50 pp.

Chablé-Santos JB, Van Wynsberghe NR, Canto-Lara SB, Andrade- Narváez FJ 1995. Isolation of Leishmania (L.) mexicana from wild rodents and their possible role in the transmission of localized cutaneous leishmaniasis in the State of Campeche, Mexico. Am J Trop Med Hyg 53: 141-145.

Cupolillo E, Grimaldi Jr G, Momen H 1994. A general classification of New World Leishmania using numerical zymotaxonomy. Am J Trop Med Hyg 50: 296-311.

Disney RHL 1968. Observations on a zoonosis: Leishmaniasis in British Honduras. J Applied Ecology 5: $1-59$.

Flores JS, Espejel Carvajal I 1994. Tipos de Vegetación de la Península de Yucatán. Etnoflora Yucatanense 3, Universidad Autónoma de Yucatán Press, Yucatán, $135 \mathrm{pp}$.

Grimaldi Jr G, Tesh RB 1993. Leishmaniases of the New World: Current concepts and implications for future research. Clin Microbiol Rev 6: 230-250.

Grimaldi Jr G, Momen H, Naiff RD, McMahon-Pratt D, Barrett TV 1991. Characterization and classification of leishmanial parasites from humans, wild mammals, and sand flies in the Amazon region of Brazil. Am J Trop Med Hyg 44: 645-661.

Grimaldi Jr G, Tesh RB, McMahon-Pratt D 1989. A review of the geographic distribution and epidemiology of leishmaniasis in the New World. Am J Trop Med Hyg 41: 687-725

Lainson R 1987. Further comments on cutaneous leishmaniasis in Belize, Central America. Trans $R$ Soc Trop Med Hyg 81: 702.

Lainson R 1997. On Leishmania enriettii and other enigmatic Leishmania species of the Neotropics. Mem Inst Oswaldo Cruz 92: 377-387.

Lainson R, Strangways-Dixon J 1963. Reservoirs hosts of Leishmania mexicana. The epidemiology of dermal leishmaniasis in British Honduras. Trans $R$ Soc Trop Med Hyg 57: 242-265.

Lainson R, Strangways-Dixon J 1964. The epidemiology of dermal leishmaniasis in British Honduras: Part II. Reservoir-hosts of Leishmania mexicana among the forest rodents. Trans R Soc Trop Med Hyg 58: 136-153.

McMahon-Pratt D, David JR 1981. Monoclonal antibodies that distinguish between New World species 
of Leishmania. Nature 291: 581-583

McMahon-Pratt D, Bennett E, Grimaldi Jr G, Jaffe CL 1985. Subspecies- and species-specific antigens of Leishmania mexicana characterized by monoclonal antibodies. J Immunol 134: 1935-1940.

Mimori T, Grimaldi Jr G, Kreutzer RD, Gomez EA, McMahon-Pratt D, Tesh RB, Hashiguchi Y 1989. Identification, using isoenzyme electrophoresis and monoclonal antibodies of Leishmania isolated from humans and wild animals of Ecuador. Am J Trop Med Hyg 40: 154-158.

Ojeda-Farfán FF 1996. Caracterización de Aislados de Leishmania spp. en Humanos y Roedores Silvestres de un Area Endémica de Leishmaniasis Cutánea en la Península de Yucatán, México, Mediante el Uso de Anticuerpos Monoclonales, Undergraduate Thesis, Universidad Autónoma de Yucatán, Mérida, Yucatán, México, 34 pp.

Pérez-Mutul J, Balám-Tzek L, Canto-Lara S 1994. Identificación de protozoarios del género Leishmania con sondas biotinadas de kDNA en la Península de Yucatán, México. Rev Bioméd 5: 60-69.

Ramírez-Fraire A 1992. Estudio de las Poblaciones de Lutzomyia spp. (Diptera: Psychodidae). Su Variación Mensual y Actividad Horario en la Zona de La Libertad, Municipio de Escárcega, Campeche, México, Undergraduate Thesis of Biology, Universidad Autónoma de Yucatán, Mérida, Yucatán, Mexico, 36 pp.
Rebollar-Téllez EA 1995. Bionomía de Lutzomyia spp. (Diptera: Psychodidae) Vectores de Leishmaniasis Cutánea Localizada en el Area Endémica del Ejido La Libertad, Escárcega, Campeche, México, MSc Thesis, Universidad Autónoma de Nuevo León, Monterrey, Nuevo León, México, 72 pp.

Rebollar-Téllez EA, Andrade-Narváez FJ, FernándezSalas I, Reyes-Villanueva F 1996b. Collections of sand flies (Diptera: Psychodidea) from mammal burrows in an area of cutaneous leishmaniasis in Campeche, Mexico. Entomol News 107: 317-321.

Rebollar-Téllez EA, Ramírez-Fraire A, AndradeNarváez FJ 1996a. A two-years study on vectors of cutaneous leishmaniasis. Evidence for sylvatic transmission cycle in the state of Campeche, México. Mem Inst Oswaldo Cruz 91: 555-560.

Seidelin H 1912. Leishmaniasis and babesiasis in Yucatán. Ann Trop Med Parasitol 6: 295-299.

Shaw JJ 1994. Taxonomy of the genus Leishmania: present and future trends and their implications. Mem Inst Oswaldo Cruz 89: 471-478.

Weigle K, de Davalos M, Heredia P, Molineros R, Saravia NG, D'Alessandro A 1987. Diagnosis of cutaneous and mucocutaneous leishmaniases in Colombia: a comparison of seven methods. Am J Trop Med Hyg 36: 489-496.

WHO - World Health Organization 1990. Control of the Leishmaniases, Technical Report Series, Geneva, Switzerland, $793 \mathrm{pp}$. 
Identification of Leishmania in Humans and Rodents • Silvia B Canto-Lara et. 